УДК 351861:355. 4]-027. 511.

https://doi.org/10.52058/2708-7530-2021-2(8)-81-96

Калясв Анатолій Олександрович кандидат історичних наук, доцент, доцент кафедри європейської інтеграції та права Львівського регіонального інституту державного управління Національної академії державного управління при Президентові України, вул. Сухомлинського, 16, м. Львів-Брюховичі, 79491, тел.: (032) 234-65-68 / факс (032) 234-63-85, e-mail: toldek@ukr. net, https://orcid.org/0000-0002-5675-187X).

\title{
РЕАЛІЗАЦІЯ СПІЛЬНОЇ ПОЛІТИКИ У СФЕРІ ВОСННОЇ БЕЗПЕКИ НАТО ТА ЄС НА ФОНІ ЗМІН ГЕОПОЛІТИЧНИХ ПОЗИЦЙ ТА ГЕОСТРАТЕГІЧНИХ ЗАВДАНЬ
}

Анотація. Державне управління у сфері безпеки у сучасному світі сприймається як один 3 найбільш важливих аспектів функціонування урядів і держав щодо недопущення глобальних воєн та уникнення регіональних конфліктів, які, 3 огляду на специфіку засобів і методів їх ведення, здатні призвести до знищення цивілізації та самого життя на нашій планеті. 3 огляду на нові геополітичні виклики та загрози основною причиною яких $є$ прагнення політичних гравців до перегляду сфер впливу, ЄС стала об'єктом як політичних так і збройних атак, головною метою яких $є$ порушення консолідованої системи управління співтовариства. 3 огляду на це $Є С$ шукає шляхи протидії через реформування своїх структур безпеки та оборони, досягнення високого рівня консолідованості в управлінні ними.. У цьому контексті важливим аспектом $\epsilon$ побудова спільної політики СС та НАТО, де головною причиною розбіжностей $\epsilon$ позиція США, як основної військової сили Альянсу. В міру того як НАТО долає виклики XXI сторіччя, широкий і різноманітний спектр різних активів, умінь, знань, сил і засобів може забезпечити НАТО перевагу над супротивниками. Європейська стратегія безпеки стала одним 3 важливих етапів в суттєвому зближенні позицій НАТО та ЄС. Доведено, що ефективна співпраця між НАТО і $\mathrm{EC} є$ запорукою вироблення комплексного підходу до врегулювання криз і проведення операцій, що вимагає ефективного застосування як військових, так і цивільних засобів. Пропонується 3 урахуванням всіх елементів поточної обстановки, Україні на найближчу перспективу доцільно погодитися на пропозицію НАТО й прийняти формат «асоційованого партнерства», тобто взяти курс на максимально можливе зближення з НАТО без формального вступу. Для України розвиток автономних європейських оборонних структур відкриває 
можливість для додаткового поглиблення співпраці із $\mathrm{CC}$ i паралельного посилення обороноздатності. Таке співробітництво $є$ взаємовигідним процесом, під час якого Україна робить свій внесок у безпеку Свроатлантичного регіону. Ключові слова: міжнародна безпека, колективна оборона, НАТО, СС, Європейська стратегія безпеки, співпраця.

Kalyayev Anatoliy Oleksandrovych Candidate of Historical Sciences, Associate Professor, Associate Professor of the Department of European Integration and Law, Lviv Regional Institute for Public Administration of the National Academy for Public Administration under the President of Ukraine, Sukhomlinskoho St., 16, LvivBryukhovychi, 79491, tel.: (032) 234-65-68 / fax (032) 234-63-85, e-mail: toldek@ukr.net, https://orcid.org/0000-0002-5675-187X).

\title{
IMPLEMENTATION OF THE COMMON POLICY IN THE FIELD OF MILITARY SECURITY OF NATO AND THE EU AGAINST THE BACKGROUND OF CHANGES IN GEOPOLITICAL POSITIONS AND GEOSTRATEGIC TASKS
}

\begin{abstract}
It is stated that governance in the security field in the modern world is perceived as one of the most important aspects of governments functioning and states to prevent global wars and avoid regional conflicts, which, given the specific means and methods they are waged, can lead to the destruction of civilization and life itself on our planet. Given the new geopolitical challenges and threats, the main reason for which is the desire of political players to reconsider their spheres of influence, the EU has been the target of both political and armed attacks, the main purpose of which is to disrupt the consolidated system of union governance. With this in mind, the EU is looking for ways to counter this by reforming its security and defense structures and achieving a high level of consolidation in their management. In this context, an important aspect is the construction of a common EU and NATO policy, where the main reason for differences is the position of the United States as the main military force of the Alliance. As NATO overcomes the challenges of the twenty-first century, a wide and diverse range of different assets, skills, knowledge, strengths and capabilities can give NATO an edge over its adversaries. The European Security Strategy has been an important step in the significant convergence of NATO and EU positions. It has been proven that effective cooperation between NATO and the EU is the key to developing an integrated approach to crisis management and operations that requires the effective use of both military and civilian means.

It is proposed that, taking into account all elements of the current situation, Ukraine in the near future should agree to NATO's proposal and adopt an "associated
\end{abstract}


partnership" format, i. e. to pursue the course of possible rapprochement with NATO without formal accession. For Ukraine, the development of autonomous European defense structures opens a possibility for further deepening of cooperation with the EU and parallel strengthening of defense capabilities. Such cooperation is a mutually beneficial process during which Ukraine contributes to the security of the Euro-Atlantic area.

Keywords: international security, collective defense, NATO, EU, European security strategy, cooperation.

Постановка проблеми (постановка проблеми у загальному вигляді та іiі зв’язок з важливими науковими чи практичними завданнями). Управління у сфері безпеки у сучасному світі сприймається як один 3 найбільш важливих аспектів функціонування урядів i держав щодо недопущення глобальних воєн та уникнення регіональних конфліктів, які, з огляду на специфіку засобів і методів їх ведення, здатні призвести до знищення цивілізації та самого життя на нашій планеті. Сучасні події в світі, пов'язані з низкою збройних протистоянь у різних регіонах, активізацією сепаратистських рухів, відцентрових тенденцій, характерних для позицій окремих країн-членів інтеграційних структур, актуалізували проблему недосконалості тих систем глобальної та регіональної безпеки, що склалися історично i впродовж другої половини ХХ ст. функціонували на основі реалізації принципу непорушності територіальної цілісності та кордонів держав за підсумками Другої світової війни. На рубежі XX - XXI ст. перед структурами міжнародної безпеки постали завдання протидії тим засобам гібридних воєн, інформаційних диверсій, які надають фінансову, військову та дипломатичну підтримку деструктивних сил на території різних країн. Ці сили вносять хаос у політичні процеси, провокують недовіру до чинних політичних інститутів та загрожують не тільки засадам міжнародного права, але й самому існуванню сучасного світового порядку. Усвідомлення відповідальності глобального управління за вибір найбільш ефективних підходів і принципів організації регіональних та глобальних інтеграційних структур та систем безпеки, сумісних і здатних до взаємодії на глобальному рівні, обумовлює необхідність розробки тих теоретичних концепцій, реалізація яких на практиці здатна убезпечити майбутнє людства на основі консолідованих здобутків міжнародного досвіду. У цьому зв’язку особливої ваги набуває досвід вирішення питань війни, миру та безпеки, як цінності, яку держави покликані оберігати й захищати як на національному, так і на глобальному та регіональному рівні. 3 огляду на нові геополітичні виклики та загрози основною причиною яких $\epsilon$ прагнення політичних гравців до перегляду сфер впливу, ЄС стала об’єктом як політичних так і збройних атак, головною метою яких є порушення консолідованої системи 
управління співтовариства. 3 огляду на це $\mathrm{CC}$ шукає шляхи протидії через реформування своїх структур безпеки та оборони, досягнення високого рівня консолідованості в управлінні ними. Між тим, незважаючи на наявність спільної мети, між країнами $Є C$, інтеграційними та національними безпековими інституціями є певні протиріччя щодо визначення шляхів реформування, внесків окремих країн у спільний оборонний бюджет, тощо. У цьому контексті важливим аспектом є побудова спільної політики СС та НАТО, де головною причиною розбіжностей є позиція США, як основної військової сили Альянсу. Саме це викликає необхідність аналізу сучасного стану взаємовідносин між НАТО та ЄС в контексті визначення шляхів створення ефективної системи колективної оборони.

Аналіз останніх досліджень і публікацій (аналіз останніх досліджень i публікацій в яких започатковано розв’язання даної проблеми і на які спирається автор, виділення невирішених раніше частин загальної проблеми, котрим присвячується означена стаття). Питання безпеки та оборони постійно знаходяться у центрі уваги наукової спільноти. Враховуючи міждисциплінарний характер питання, можна відзначити, що концептуальні засади міжнародної безпеки досліджувалися у працях західних авторів, зокрема, Р. Арона, 3. Бжезинського, Д. Болдуїна, К. Дойча, Е. Карра, Е. Картера, Г. Кларка, Дж. Кеннана, Р. Кеохейна, Г. Кіссінджера, С. Хоффмана, Х. Маккіндера, Е. Менсфілда, М. Михалки, Д. Мілтрані, Г. Моргентау, Дж. Ная, Р. Нібура, У. Перрі, Дж. Розенау, Дж. Снайдера, Дж. Стейнбруннера, Л. Сона, К. Уолтца, M. Xaaca, Howorth J. (2007), Mandragelya V., Novak-Kalyayeva L., Shay D., Walt S., Witney N. та інших. Розгляду деяких специфічних проблем розвитку країн європейського регіону, в тому числі й інтеграції, питань безпеки, їх геополітичного й політичного аспектів, присвятили свої роботи цілий ряд українських авторів: Ю. Борко, О. Бурсов, Л. Воробйова, А. Гальчинський, О. Гончаренко, К. Грищенко, В. Горбулін, В. Дергачов, Т. Закаурцева, Т. Зонова, I. Кузьмін, О. Литвиненко, О. Маначинський, I. Храбан, В. Чи, В. Шахов, А. Шевцова та інші.

В той же час, в умовах перманентних змін характеру збройних протистоянь, постійного удосконалення засобів нападу й оборони та посилення терористичних загроз, дослідження завдань і підходів глобального стратегічного управління у сфері безпеки набуває особливої ваги. Це підтверджує актуальність теми статті та своєчасність наукової розробки обраної проблематики.

Мета статті (формулювання цілей статті (постановка завдання). Метою статті є обгрунтування теоретичних напрямів реалізації спільної політики у сфері воєнної безпеки НАТО ТА ЄС на фоні геополітичних змін.

Завдання:

- визначити основні причини змін пріоритетів у безпековій політиці СС; 
- окреслити нові завдання у сфері колективної безпеки та оборони на фоні агресивної політики РФ;

- обгрунтування теоретичних напрямів реалізації спільної безпекової політики ЄС та НАТО.

Виклад основного матеріалу (виклад основного матеріалу дослідження 3 повним обгрунтуванням отриманих наукових результатів).

Звертаючись до витоків питання європейської безпеки, можна констатувати, система міжнародної та європейської безпеки значною мірою залежала та залежить від позицій Німеччини, Великобританії, Франції, США та Росії, які переважно були ініціаторами чи суб'єктами війн і конфліктів у період нової та новітньої історії у їх прагненні до світового лідерства. У історичній ретроспективі ці країни постійно створювали військово-політичні союзи, які, з одного боку мали на меті захоплення чужих територій та багатств і їх політика носила агресивнонаступальний характер. 3 іншого боку, їх противники створювали оборонні союзи та системи колективної безпеки, які через постійну боротьбу за геополітичні впливи не були ефективними.

Від часів закінчення другої світової війни американська військова присутність та особливо ядерна складова НАТО гарантували безпеку країнамчленам Альянсу, яка базувалась на принципах колективної та територіальної оборони. Під фактичною військово-політичною опікою США рівень економічного розвитку, якість життя та громадянських прав і свобод в країнах Свросоюзу досягли найвищих у світі стандартів. Саме тому, країни Західної Свропи не формували спільної політики у сфері зовнішньої політики, безпеки та оборони. Зосередивши інтеграційні процеси у соціально-економічній та суспільнополітичній площині, вони не бачили нагальної потреби активізуватися у цій сфері, 3 огляду на гарантії НАТО [1, Р. 129].

Процес інтеграції європейських країн у сфері безпеки було розпочато укладанням 17 березня 1948 р. між Бельгією, Великобританією, Люксембургом, Нідерландами і Францією, Брюссельського договору, який. передбачав спільну діяльність в економічній, соціальній i культурній галузях та колективну самооборону. На початку 50-х років XX ст. в Європі виникають спроби створити власну структуру безпеки. 27 травня 1952 р. договір про Європейське оборонне співтовариство (СОС) був підписаний Бельгією, Італією, Люксембургом, Нідерландами, Францією та ФРН. Європейське оборонне співтовариство мало "наднаціональний характер", загальні інститути, загальні збройні сили та загальний бюджет.. До основних цілей ЗСС слід віднести “...надання військової та іншої взаємодопомоги як у підтримці міжнародного миру і безпеки, так і в протидії будь-якій агресивній політиці; сприяння єдності Європи; тісне співробітництво з НАТО; зміцнення і забезпечення демократії, особистої та 
політичної свободи, конституційних традицій, поваги до закону; встановлення більш тісних економічних, соціальних і культурних зв’язків між державамиучасницями”. ЄС сприяв формуванню договірних та інституційних засад спільної політики безпеки і оборони. Хоча формування європейської системи безпеки $\mathrm{i}$ здійснювалося європейськими країнами, які були країнами - членами ЄС, проте європейська політика безпеки проводилася на базі НАТО. Одним з головних завдань СС, визначеного Маастрихтським договором від 7 лютого 1992 року - $є$ проведення загальної зовнішньої політики і політики безпеки та оборони. Разом із тим розвиток та формування такої політики безпеки відбувалося за рахунок об'єднання зусиль ЄС і НАТО. СС і НАТО встановили офіційні стосунки в січні 2001 р. А 16 грудня 2002 р. було прийнято Декларацію СС - НАТО про Спільну Європейську політику у сфері безпеки і оборони (ССПБО, ЄПБО). Ухвалені рішення свідчили про певну корекцію світогляду політичного керівництва країн ЄС та поступове посилення намірів розвивати концепцію безпеки, безпосередньо зорієнтовану на європейський політичний простір та втілення колективних інтересів держав ЄС у сфері міжнародної безпеки. Найважливішим документом щодо розвитку європейської системи колективної безпеки на початку XXI століття виявилася ухвалена в грудні 2003 року Європейська стратегія безпеки (ССБ).

Між тим, на початку століття почали формуватися, як нова позиція США, так i прагнення $\mathrm{CC} \mathrm{стати} \mathrm{самостійним} \mathrm{центром} \mathrm{сили} \mathrm{із} \mathrm{власним} \mathrm{курсом} \mathrm{у} \mathrm{світовій}$ політиці, спроможним захистити свої інтереси, що призвело до перегляду позицій ЄC. Разом з тим, швидке розширення ЄС загальмувало процеси координації зусиль європейських країн у галузі безпеки й оборони.

В. Мандрагеля виділяє три хвилі реформ системи безпеки ЄС. Спочатку (протягом 2003 - 2005 років) увага спрямовувалася на розвиток всебічного антикризового управління. У 2006 - 2008 роках головні зусилля концентрувалися на вдосконаленні структур та зміцненні можливостей антикризового управління. 3 середини 2008 року стає помітною інша тенденція - спроба пристосувати ЄПБО до ширшого політичного контексту, тісніше зв’язати ієрархічну структуру 3 3ЗППБ, з інструментами та ресурсами Сврокомісії [2, С. 135].

Різні інтереси членів СС, а також ресурси i, що важливіше, різна культура безпеки перетворилися на чинники, що рухали інституціональні реформи в площині СПБО [3, Р. 22].

Незважаючи на зусилля СС добитися більшої кооперації у сфері оборони існує ряд проблем у взаємовідносинах країн-членів, що пов’язані перш за все 3 прагненням окремих членів до поділення сфер впливу а також громіздка інституційна структура безпекової сфери, що призводить до проблем 3 оперативним прийняттям воєнно-політичних рішень. 
Окрім того, Євросоюзу доводиться конкурувати у сфері безпеки з НАТО, ОБСС, ООН. Це значною мірою різні інститути, з різними підходами і потенційно конфліктними інтересами. Зважаючи на неможливість розв'язати проблеми, що виникають у сфері безпеки між тими організаціями, у 2006 році держави СС погодилися на так зване «довгострокове бачення" (Long Term Vision - LTV) для розвитку можливостей. Особлива увага при цьому зверталася на засоби комунікації та розвідки, високоточну зброю і засоби захисту, розвиток транспорту і технічно-тилового забезпечення [4].

ЄПБО, відповідно до Лісабонського Договору, перейменована на Загальну безпекову і оборонну політику - ЗБОП (Common Security and Defence Policy CSDP). Для досягнення успіху $\mathrm{CC}$ необхідно зосередитися на виконанні таких завдань: рішучі, термінові дії на ключових напрямках оборонного сектора; наполегливе об'єднання зусиль і ресурсів; підвищення ефективності діяльності Європейської оборонної агенції (СОА). [5, Р. 33-34].

Свропейське оборонне агентство(ЕОА) $є$ ключовим інститутом Свропейського союзу у реалізації заходів по ресурсному забезпеченню Загальної політики безпеки і оборони(ЗПБО). Перед Агентством були поставлені завдання щодо розвитку військової ресурсної бази, оборонних наукових досліджень і розробок, загальноєвропейських проектів співпраці по озброєннях, посилення індустріально-технологічної бази i, в якості головного орієнтиру, створення спільного конкурентоздатного ринку продукції військового i подвійного призначення. Для досягнення поставлених цілей ЕОА були затверджені стратегічні ініціативи, що стали концептуальною основою діяльності цього органу. Проте за минулі роки Агентству не вдалося добитися серйозних результатів, воно лише частково просунулося в цьому напрямі.

На думку більшості зарубіжних дослідників головною причиною формування європейської політики безпеки і оборони (СПБО) стала певною мірою гегемоністська позиція США та прагнення європейців створити автономну систему колективної безпеки для реалізації $Є С$ власного курсу у світовій політиці, зменшити залежність від США і розвинути спроможності для захисту своїх інтересів [6, Р. 129].

3 огляду на військово-політичне протистояння України та Російської Федерації, проблеми безпеки в Європі набули особливої актуальності. У комплекс причин, що обумовлюють такий характер згаданих проблем входять страх перед політикою Росії на пострадянському просторі, позиція нових членів СС колишніх Радянських Республік і колишніх соціалістичних країн Центральної і Східної Європи. Країни Центральної та Східної Європи розбудовують системи національної безпеки виходячи із власних національних інтересів, бачення i аналізу політичних процесів, що відбуваються у світі, політичного досвіду і і 
професійної компетенції політичних еліт. Особливий характер має партнерство Росії $з$ цими країнами.

Більш країн Європи є членами Організації Північно-атлантичного договору НАТО. Свроатлантичний альянс $є$ вагомою складовою систем національної безпеки домінуючої кількості країн Центральної та Східної Свропи.

Більшість країн Центральної і Східної Свропи свої системи безпеки пов'язують із США, визначаючи їх провідну роль у забезпеченні між народної безпеки. США відведена вагома роль у Європейській загальній політиці безпеки. Свроатлантична система безпеки на основі НАТО охоплює не усі країни, отже для запобігання конфліктам в Свропі і за їі межами потрібно консолідувати зусилля усіх держав регіону. Можливо доцільно на порядок денний поставити питання повернення ОБСЄ функцій, визначених для неї засновницькими документами, перетворення ОБСЄ в стержневий елемент системи регіональної безпеки, що надасть можливість розширити іiі повноваження по запобіганню і врегулюванню конфліктів, у тому числі по проведенню миротворчих операцій та вдосконалення контролю над озброєннями в зоні відповідальності ОБСЄ.

В контексті переорієнтації дій НАТО на забезпечення колективної оборони повсякденна діяльність НАТО, яка розгортає нові підрозділи в своїх східних країнах-членах, проводить великі навчання, протидіє кіберзагрозам і тероризму, $\mathrm{i}$ приймає до своїх лав нових членів, протирічить політичним заявам про те, що НАТО ніби то є застарілим Альянсом, що потребує великих фінансових витрат. Водночас багато скептиків вважають, що його боєздатність знаходиться на низькому рівні, особливо після зміни позиції США, які почали вимагати збільшення витрат на отримання структури. Між тим, на думку європейських аналітиків, Альянс сьогодні діє в найбільш складному середовищі безпеки за усю свою історію. Він має справу зі спектром загроз, різноманітним як ніколи. Якщо не вдасться впоратися 3 тими загрозами то вони можуть покласти край ліберально-демократичним суспільствам, правам та свободам людини, які громадяни країн НАТО сьогодні сприймають як належне . Роль НАТО повинна полягати в активному стимулюванні і пошуку шляхів поєднання різних внесків задля максимального стратегічного результату. В міру того як НАТО долає виклики XXI сторіччя, широкий і різноманітний спектр різних активів, умінь, знань, сил і засобів може забезпечити НАТО перевагу над супротивниками.

Наступною сферою активних дій Альянсу є забезпечення прозгалуженого та структурованого партнерства, що засноване на взаємній вигоді.. Партнерство 3 членами Альянсу робить роль партнерів в міжнародній безпеці більш істотною. Водночас зміна пріоритетів НАТО у бік колективної оборони поставило питання партнерства на другий план. Відбудова партнерств може допомогти переконати громадськість в тому, що Альянс має політичний, а не суто військовий підхід до 
безпеки. I головне, щодо вирішення питання європейської оборони в контексті створення власних збройних сил, то дебати щодо того, чи має існувати Європейська армія, чи Європейська стратегічна автономія, не припиняються. Одні хочуть посилення європейських сил і засобів без окремих інституцій; інші інституцій, не переймаючись занадто додатковими силами і засобами. Декотрий час стверджували, що власне європейська оборонна структура потрібна як запобіжник у разі відокремлення США. В інший час вона вважається способом зміцнення Альянсу i трансатлантичного партнерства через подолання розпорошеності європейських оборонних бюджетів і програм закупівель і надання більшого впливу СС за рахунок збільшення програм співробітництва. Періодичні декларації окремих провідників ЄС щодо створення Свропейської армії в умовах проблематичності прийняття рішень в СС більше виглядають черговою спробою видати бажане за дійсне, і найближчим часом перспективи не мають. Особливо 3 огляду на те, що питання недостатнього фінансування європейськими країнами потреб оборони та безпеки стало вже хронічною проблемою для країн-членів СС. Тому реально перспективною поки що виглядає запровадження більш жорстких режимів безпеки у громадських місцях та посилення співпраці правоохоронних органів європейських країн 3 питань боротьби 3 проявами тероризму, нелегальною міграцією, організованою злочинністю, незаконним обігом наркотиків тощо [7, С. 10].

СС сьогодні опинився перед новими викликами та загрозами, що зумовлені як внутрішніми та зовнішніми чинниками, що мають розмитий характер через глобалізацію. Саме це змушує європейців взяти на себе більшу відповідальність за безпеку на континенті і навколо нього. Свропейська стратегія безпеки стала одним з важливих етапів в суттєвому зближенні позицій НАТО та ЄС. Ефективна співпраця між НАТО і СС є запорукою вироблення комплексного підходу до врегулювання криз і проведення операцій, що вимагає ефективного застосування як військових, так i цивільних засобів. Перспективи створення надійної майбутньої системи Свропейської безпеки значною мірою залежать від того, як швидко Свропа зможе зробити належні висновки з поточної кризи і прийняти адекватні рішення [8, С. 86-92].

Європейська політика безпеки і оборони ЄС є частиною Спільної зовнішньої політики і політики безпеки (СЗППБ). За Лісабонським договором СЗППБ фактично складається з двох частин: спільної зовнішньої політики і їі автономної складової - європейської політики безпеки і оборони (ЄПБО). Криваві конфлікти на кордоні з ЄС зробили проблему безпеки слабким місцем європейського інтеграційного проекту. Тепер Європа знаходиться у “вогняному кільці”, яке пролягає через Близький Схід i Кавказ аж до кордонів України. На думку провідних європейських політиків, причиною виникнення такої ситуації $\epsilon$ 
скорочення витрат СС на армію [9, С. 102-107]. Крім того, між країнамиучасницями немає єдності і довіри, вони по-різному оцінюють небезпеки. Свропейська політика безпеки та оборони виявилась неефективною перед новими викликами та загрозами, тому для структур ЄС стала актуальною проблема іï реформування Все це створює перешкоди у побудові єдиної безпекової стратегії. На порядок денний стає потреба у створенні Свропейського оборонного союзу, який допомагатиме НАТО [10, С. 30-37]. Ідея практичного наповнення спільної оборонної і безпекової політики (СПБО) ЄС оформилася у червні 2016 році 3 представленням нової Глобальної стратегії із зовнішньої та безпекової політики, яка змінила попередній документ від 2003 р. Стратегія під назвою “Спільне бачення, спільні дії: сильніша Європа" [11]. відобразила колективну думку країнчленів і запропонувала стратегічне бачення глобальної ролі ЄС. Вона стала уособленням нового погляду на захист спільного майбутнього Європи, який став консолідованим для проєвропейських сил у Євросоюзі. За задумом членів Свропарламенту, швидке створення Європейського оборонного союзу в партнерстві з НАТО дозволить ЄС діяти автономно в операціях за кордоном для стабілізації сусіднього простору і підвищення своєї ролі як гаранта безпеки. Резолюція Європарламенту пропонувала заснувати Головне управління з питань оборони, яке б на рівні Свросоюзу відповідало за внутрішні аспекти політики оборони і безпеки, а також створити Європейський розвідувальний відділ. Напрацювання Сврокомісії, Свропраламенту, інших керівних органів вилилися у прийняття на грудневому 2016 р. засіданні Ради СС на рівні глав держав та урядів низки документів, об’єднаних у т. зв. “Зимовий пакет” з Європейської безпеки i оборони (2016 EU Security and Defense WinterP ackage) [12]. До нього увійшли: нові політичні цілі і наміри у сфері безпеки й оборони - План імплементації Глобальної стратегії СС з питань безпеки та оборони (Implementation Plan on Security and Defence); фінансові засоби, визначені в Свропейському оборонному плані дій (European Defence Action Plan); комплект пропозицій 3 виконання Спільної декларації ЄC-HATO (EU- NATO Joint Declaration). У розвиток цих рішень лідери країн Свросоюзу прийняли Римську декларацію, яка містить зобов'язання започаткувати союз країн-членів СС, який допоможе створити більш конкурентоспроможну і інтегровану оборонну промисловість і зміцнить спільну безпеку і оборону у співпраці та взаємодоповнюваності з НАТО. На початку грудня 2017 року Рада ЄС прийняла рішення про запуск програми Permanent Structured Cooperation (PESCO) - Постійної структурованої співпраці у сфері оборони країн-членів ЄC [13]. Програма дозволить спільно протистояти військовим загрозам з боку Росії і підсилити обороноздатність Свросоюзу, якщо цьому не перешкодять суперечки між учасниками. Участь в PESCO $\epsilon$ добровільною для всіх країн-членів ЄС. Згодом до 23 країн, які у листопаді 2017 
року підписали офіційну заяву про розширення співпраці, приєдналися також Ірландія і Португалія. Натомість до нового об’єднання не увійшли Данія, Мальта та Великобританія. Головною метою у сфері оборони стратегія проголошує збільшення потенціалу СС діяти автономно від НАТО у випадку необхідності, посилення його безпекових можливостей через поглиблення взаємодії між державами-членами щодо ефективного використання наявних ресурсів разом iз паралельним збільшенням оборонних бюджетів. На шляху військової співпраці країн ЄС є ризик виникнення складнощів і розбіжностей, наприклад у питаннях розподілу воєнних контрактів, коли певна країна отримає те або інше оборонне замовлення. Сьогодні в рамках PESCO працюють 17 проектів з підготовки військ і розвитку бойового потенціалу, реагування на кризові ситуації, перекидання військових контингентів, посилення морської безпеки i реагування на кіберзагрози. Офіційний список видів співпраці налічує більш 50 безпекових та оборонних проектів. В рамках інституалізації безпекових орієнтирів було запропоновано створити окрему штаб-квартиру, яка б керувала усіма операціями ЄC за кордоном. На першому етапі із загальноєвропейського центру мають координуватися питання надання медичної допомоги, спільного використання транспортної авіації, обміну даними розвідки. Франко-німецькі ініціативи передбачали також повну бойову готовність спільних бойових тактичних груп, а також запровадження спільного бюджету на розробку і закупку транспортної авіації, супутників, БПЛА i кіберзасобів. Першим результатом таких інтеграційних ініціатив стало утворення військового штабу СС (Military Planning Conduct and Capability Facility). Хоча поки що він і не є класичним повноцінним військовим штабом, але відповідатиме за військові операції ЄС. Однією з причин нової оборонної ініціативи СC PESCO стала непередбачувана безпекова політика американського президента Д. Трампа, та “брекзит” Великобританії, побоювання, що США відмовляться від своїх зобов'язань в НАТО, а також бажання більшої автономії $\epsilon C$ у питаннях європейської безпеки. Однак $€ C$ зовсім не планує відмежовуватись від НАТО, а натомість поглиблює співпрацю 3 альянсом. На думку експертів, без американських військово-стратегічних, супутникових, розвідувальних можливості та технологій ППО Європа безсила. Реалізація проектів PESCO повинна покращити оборонну потужність країн-членів СC, зокрема здатність протистояти викликам та загрозам з боку Росії. Сьогодні країни ЄC не здатні поодинці гарантувати свою безпеку в разі загрози військового конфлікту, адже їхні оборонні витрати i потенціал у сфері безпеки не відповідають вимогам сучасності [14]. В рамках цих оборонних ініціатив Свропейське командування США (USEUCOM) провело у 2019 році серію навчань негайного реагування в Хорватії, Угорщині і Словенії. Серія навчань USEUCOM об’єднує союзників і партнерів по НАТО для підвищення оперативної сумісності. 
Метою навчань є створення підготовлених спільних сил, готових для виконання повного спектру військових завдань по захисту національних інтересів, стримування російської агресії і підтримки стабільної і безпечної Європи.

Таким чином, об'єднаній Європі вдалося за останній рік пройти шлях від окремих пропозицій щодо того, як активізувати співпрацю у сфері безпеки i оборони, до конкретних затверджених планів, які виглядають достатньо амбітними. У Свропейському Союзі вже розпочалось переосмислення важливості самостійної здатності протистояти загрозам, він отримав стратегічну автономію та підняв питання СПБО на найвищий щабель уваги - на рівень глав держав. Крім прийняття політичних рішень, з реалізації Глобальної стратегії були зроблені певні практичні кроки щодо посилення цього безпеково-оборонного виміру в EC [15, C. 17-33].

По-перше, було схвалено низку документів, об’єднаних в т. Зв. “Зимовий пакет” з Європейської безпеки і оборони, які стали рамочними для прийнятого пізніше плану “постійного структурного співробітництва”.

По-друге, Свросоюз посилив свої оборонні управлінські структури. Кроком у реалізації Глобальної стратегї ЄС стало створення військового штабу СС.

По-третє, створення військового штабу СС викликало експертні дискусії про створення власне “європейської армії”. Сьогодні малоймовірно, що Євросоюз зробить такий крок. Формування “європейської армії” створює ризики розколу трансатлантичної єдності, адже не всі країни СС підтримують цю ідею, та й провести лінію розмежування між повноваженням СС і НАТО у сфері безпеки та оборони вкрай складно. Однак, окремі елементи спільної політики у сфері безпеки i оборони реалізуються у Євросоюзі вигляді бойових тактичних груп, а також ведуться експертні дискусії про можливість створення т. зв. “оборонного союзу”

По-четверте, активізувалась співпраця між СС і НАТО, що також було передбачено Глобальною стратегією. Для Свросоюзу Альянс залишається опорою в Свропі з точки зору протистояння воєнним загрозам, оскільки жодна країначлен $Є С$ не має достатніх військових можливостей. Одним 3 вдалих прикладів співробітництва між СС та НАТО у сучасних умовах та нових викликах стало підписання у квітні 2017 р. країнами-членами ЄС та НАТО угоди про заснування у Гельсінкі Центру протидії гібридним загрозам.

По-п’яте, країни Свросоюзу змушені переглянути національні оборонні витрати. Низка країн вже заявили про збільшення оборонних витрат. 17 червня 2019, міністри оборони Німеччини, Франції та Іспанії затвердили найбільший в Європі оборонний проект - систему ведення повітряних боїв майбутнього яка має бути готова до бойового використання до 2040 року. Система включатиме не лише бойові літаки але також супровідні загони безпілотників, флагманські i патрульні літаки, наземні станції i супутники. Загальна вартість проекту 
оцінюється в суму до 50 мільярдів євро. Також цього ж дня, міністри закордонних справ і оборони всіх 28 країн Євросоюзу затвердили "Глобальну стратегію ЄС", у якій описані спільні оборонні та безпекові спроможності та розглянуті шляхи подальшого зміцнення ролі Свросоюзу як глобального гравця.

Активізувалася співпраця між СС і НАТО, що також було передбачено Глобальної стратегії. Для Євросоюзу Альянс залишається опорою в Європі 3 точки зору протистояння військовим загрозам, оскільки жодна країна-член не має достатніх військових можливостей. Одним з вдалих прикладів співпраці між СС i НАТО в сучасних умовах і нові виклики стало підписання в квітні 2017 країнамичленами СС і НАТО угоди про заснування в Гельсінкі Центру протидії гібридним загрозам.

Крім того, країни Євросоюзу були змушені переглянути національні оборонні витрати. Ряд країн вже заявили про збільшення оборонних витрат. 17 червня 2019, міністри оборони Німеччини, Франції та Іспанії затвердили найбільший в Європі оборонний проект - систему ведення повітряних боїв майбутнього яка повинна бути готова до бойового використання до 2040 року. Система буде включати не тільки бойові літаки але також супровідні загони безпілотників, флагманські і патрульні літаки, наземні станції і супутники. Загальна вартість проекту оцінюється в суму до 50 млрд євро. Також в цей же день, міністри закордонних справ і оборони всіх 28 країн Свросоюзу затвердили "Глобальну стратегію СC", в якій описані загальні оборонні та безпекові можливості і розглянуті шляхи подальшого зміцнення ролі Свросоюзу як глобального гравця

Висновки. Таким чином, перед світовою спільнотою стоять виклики нового типу, відповіді на які поки що не знайдені. Очевидно, що існуюча система міжнародної безпеки, по суті, себе вичерпала. Вона не здатна працювати на попередження загроз. Разом із тим, як ніколи зросла актуальність військової загрози для європейської безпеки. У цих умовах виникає необхідність визначення нового формату взаємодії країн, вироблення правил, які будуть закладені в основу формування нової системи міжнародної безпеки. У перспективі базовим елементом більш глобальної архітектури міжнародної безпеки повинен стати НАТО. Зона його відповідальності повинна бути розширена і за певних обставин вийти за рамки, окреслені кордонами держав-членів. Необхідно забезпечити єдність та сумісність військово-стратегічних планів усіх оборонних інститутів ЄС різних рівнів з НАТО зі створенням системи централізованого управління (об’єднаного командування)рішення якого повинні бути обов'язковими для виконання усіма країнами, що входять у систему колективної оборони. Це передбачає можливість обмеження національних суверенітетів настільки, наскільки це вимагає військово-політична ситуація. Важливо оптимізувати усі 
оборонні інститути за рахунок інформатизації систем управління, забезпечення управлінськими кадрами вищої кваліфікації, що мають досвід в антикризовому управління та організації протидії гібридним загрозам.

Діюча «Стратегія національної безпеки України» передбачає інтеграцію до ЄС і вступ до НАТО, i, так само, як і «Європейська стратегія безпеки» однією 3 основних цілей визначає утвердження загальнолюдських цінностей : «.... утвердження прав і свобод людини і громадянина, забезпечення нової якості економічного, соціального і гуманітарного розвитку, забезпечення інтеграції України до Свропейського Союзу та формування умов для вступу в НАТО» [16]. 3 урахуванням всіх елементів поточної обстановки, Україні на найближчу перспективу доцільно погодитися на пропозицію НАТО й прийняти формат «асоційованого партнерства», тобто взяти курс на максимально можливе зближення з НАТО без формального вступу (Шведсько-фінський варіант) [17]. Розглядаючи перспективи поглиблення співробітництва між Україною та ЄС у сфері безпеки та оборони, треба брати до уваги, що Глобальна стратегія ЄС iз зовнішньої і безпекової політики містить важливий напрям - «працювати 3 ключовими партнерами, державами і регіональними об'єднаннями, які поділяють погляди ЄС». За цим критерієм Україна є важливим партнером Євросоюзу на Сході. У стратегії наша держава відзначена у розділі «Свропейська система безпеки», у контексті протидії агресії Росії, що підтверджує їі ключову важливість для безпеки ЄС та визначає перспективність такого виміру співпраці.

Для України розвиток автономних європейських оборонних структур відкриває можливість для додаткового поглиблення співпраці iз ЄC i паралельного посилення обороноздатності. Таке співробітництво $\epsilon$ взаємовигідним процесом, під час якого Україна робить свій внесок у безпеку Свроатлантичного регіону, а з іншого боку, в процесі навчань і тренувань отримує необхідний досвід.

Отже, власне партнерський підхід до подальшого розвитку співпраці України з СС у сфері зовнішньої політики і безпеки окреслює три напрями:

- взаємодія України і СС у міжнародному i регіональному вимірах заради спільної безпеки;

- $\quad$ допомога СС у зміцненні стійкості і безпеки України;

- $\quad$ внесок України у безпеку Свропи.

Очевидно, що в подальшому міжнародний і регіональний виміри співпраці України і СС спиратимуться на всебічну підтримку України Свросоюзом у питаннях, що стосуються суверенітету, територіальної цілісності, захисту національних інтересів, безпеки держави і людини. Зі свого боку, Україна має підтримувати політику ЄС, дотримуватись європейських цінностей та стати їхнім провідником у регіональному вимірі, перш за все в рамках формату Східного 
партнерства. Головним внеском України до безпеки Свропи є зміцнення власної обороноздатності і стримування російської агресії на своїх східних кордонах.

\section{Лimepamypa:}

1. Walt S. Taming American Power: The Global Response to US Primacy. New York: Norton. 2005. P. 129.

2. Мандрагеля В. Європейська система колективної безпеки: інституціональні проблеми. Політичний менеджмент. 2011. С. 133-140. С. 135.

3. European Security and Defence Policy. The first 10 Years (1999 - 2009) / Eds. Giovanni Grevi, Damien Helly and Daniel Keohane. Paris, The European Union for Security Studies. 2009. P. 22.

4. Офіційний сайт НATO (10 листопада 2010 р.). URL: http://www. nato. int/docu/basictxt/b061129e. htm.

5. Witney N. Re-energising Europe's Security and Defence Policy. London: European Council on Foreign Relations. 2008. P. 33-34.

6. Walt S. Taming American Power: The Global Response to US Primacy. New York: Norton. 2005. P. 129.

7. Шей Д. Альянс переорієнтовує увагу на свою основну місію колективної оборони. НАТО Ревю від 30. 09. 2019. С. 10-19. С. 10.

8. Каляєв А. О. Обороноздатність країн СС в контексті сучасних проблем системи колективної безпеки. Розвиток публічного управління в Україні: матеріали наук. практ. конференції ЛРІДУ НАДУ. Львів. 2020. С. 86-92.

9. Пашинський В. Досвід публічного управління обороною у провідних країнах НАТО. Наџіональний юридичний журнал: теорія і практика. 2019. №1. С. 102-107.

10. Труш О. О., Нікіпєлова С. М. Історико-правові засади європейської політики безпеки й оборони. Теорія та практика державного управління. 2016. Вип. 3. C. 30-37. URL: http://nbuv. gov. ua/UJRN/Tpdu_2016_3_7.

11. Глобальна стратегія із зовнішньої та безпекової політики" Спільне бачення, спільні дії: сильніша Європа" ЄC. 2016. URL: https://europa. eu/globalstrategy/en/europeansecuritystrategy-secure-europe-better-world.

12. The 2016 "Winter Package" on European Security and Defence: Constitutional, Legal and Institutional Implications. Manuscript completed on 16 December 2016 (C) European Union, 2016 This document is available on the internet at: http://www. europarl. europa. eu/supporting-analyses EU Energy Policy: Engaging with Partners beyond Our Borders, Eur-Lex. (no year, n. d. ). URL: http://eurlex. europa. eu/legal-ntent/EN/TXT/?qid=1408370068358.

13. Permanent Structured Cooperation (PESCO) - factsheet. URL: https://eeas.europa. eu/headquarters/headquarters-Homepage/34226/permanent-structured-cooperation-pesco-factsheet_en.

14. Александров С. О. Розвиток спільної зовнішньої та безпекової політики Європейського Союзу. Перспективи для України. URL: http://old2.niss.gov.ua/content/articles/ files/Aleksandrov-91492. pdf.

15. Каляєв А. О. Шаповал О. М. Інституціональні проблеми безпеки та оборони ЄС у контексті розширення співробітництва з Україною. Ефективність державного управління: зб. наук. праць ЛРІДУ НАДУ. Львів. 2020. № 3(64). С. 17-33.

16. Про Стратегію національної безпеки України: Указ Президента України; Стратегія від 26.05.2015 № 287/2015 URL: https://zakon.rada.gov.ua/laws/show/287/2015. 
17. Поляков Л. А. Україна і криза європейської безпеки: оцінки і перспектив. Нова Україна. Інститут стратегічних досліджень. URL: http://newukraineinstitute. org/blog/211.

\section{References:}

1. Walt, S. (2005). Taming American Power: The Global Response to US Primacy. New York.: Norton. P. 129.

2. Mandragelya, V. (2011). European system of collective security: institutional problems Political Management. P. 133-140. P. 135. [in Ukrainian].

3. European Security and Defence Policy (2009). The first 10 Years (1999 - 2009) / Eds. Giovanni Grevi, Damien Helly and Daniel Keohane. Paris, The European Union for Security Studies, P. 22.

4. NATO's official website November 10, 2010. URL: http://www.nato.int/docu/basictxt/b061129e.htm.

5. Witney, N. (2008). Re-energising Europe's Security and Defence Policy. London: European Council on Foreign Relations. P. 33-34.

6. Walt, S. (2005). Taming American Power: The Global Response to US Primacy. New York.: Norton. P. 129.

7. Shei, D. (2019). Alians pereoriientovuie uvahu na svoiu osnovnu misiiu kolektyvnoi oborony. NATO Reviu 30.09.2019. S.10-19 S.10 [in Ukrainian].

8. Kalyayev, A. O. (2020). Oboronozdatnist krain YeS v konteksti suchasnykh problem systemy kolektyvnoi bezpeky. Rozvytok publichnoho upravlinnia v Ukraini:materialy nauk.prakt. konferentsii LRIDU NADU. Lviv. S. 86-92. [in Ukrainian].

9. Pashynskyi, V. (2019). Dosvid publichnoho upravlinnia oboronoiu u providnykh krainakh NATO. Natsionalnyi yurydychnyi zhurnal: teoriia i praktyka. №1. S. 102-107 [in Ukrainian].

10. Trush, O. O., Nikipielova, Ye. M. (2016) Istoryko-pravovi zasady yevropeiskoi polityky bezpeky y oborony Teoriia ta praktyka derzhavnoho upravlinnia. Vyp. 3. S. 30-37. URL: http://nbuv.gov.ua/UJRN/Tpdu_2016_3_7.

11. Hlobalna stratehiia iz zovnishnoi ta bezpekovoi polityky "Spilne bachennia, spilni dii: sylnisha Yevropa" YeS. (2016). URL: https://europa.eu/globalstrategy/en/european-securitystrategysecure-europe-better-world. [in Ukrainian].

12. The 2016 "Winter Package" on European Security and Defence: Constitutional, Legal and Institutional Implications. Manuscript completed on 16 December 2016 (C) European Union, 2016 This document is available on the internet at: http://www. europarl. europa. eu/supporting-analyses EU Energy Policy: Engaging with Partners beyond Our Borders, Eur-Lex. (no year, n. d. ). URL: http://eurlex. europa. eu/legal-ntent/EN/TXT/?qid=1408370068358.

13. Permanent Structured Cooperation (PESCO) - factsheet. URL: https://eeas.europa. eu/headquarters/headquarters-Homepage/34226/permanent-structured-cooperation-pesco-factsheet_en.

14. Aleksandrov, S. O. Rozvytok spilnoi zovnishnoi ta bezpekovoi polityky Yevropeiskoho Soiuzu. Perspektyvy dlia Ukrainy // analitychna dopovid. URL: http://old2.niss.gov.ua/content/articles/files/Aleksandrov-91492.pdf. [in Ukrainian].

15. Kalyayev, A. O. Shapoval, O. M. (2020). Instytutsionalni problemy bezpeky ta oborony YeS u konteksti rozshyrennia sprivrobitnytstva z Ukrainoiu. Efektyvnist derzhavnoho upravlinnia: zb.nauk.prats LRIDU NADU. Lviv. № 3(64). S.17-33 [in Ukrainian].

16. Stratehiia natsionalnoi bezpeky: Ukaz Prezydenta Ukrainy vid 26 travnia 2015 roku № 287/2015. URL: https://www.president.gov.ua/documents/2872015-19070. [in Ukrainian].

17. Poliakov, L. A. Ukraina i kryza yevropeiskoi bezpeky: otsinky i perspektyv. Nova Ukraina. Instytut stratehichnykh doslidzhen. URL: http://newukraineinstitute.org/blog/211. [in Ukrainian]. 